\title{
DETERMINANTS OF DIVIDEND PAYOUT: AN EMPIRICAL STUDY OF NIFTY-100 FIRMS
}

\author{
Dr. Chinnaiah.P.M, \\ Assistant Professor DOS\& R in Management, KSOU, Mysuru.
}

Article DOI: https://doi.org/10.36713/epra5212

\begin{abstract}
Dividend decision is one of crucial decisions a manager has to take. It deals with either to retain or distribution of earnings. Though there are large number of researches have been conducted on the determinants of dividend payout, they have come up with different determinants of dividend payout. Some of these are common across industries and some are different from industry to industry and vary from one country to another. Since Nifty100 index is one of the widely diversified and which covers more than 70 percent of market capitalization of overall firms listed on the NSE as on march 2009. Hence, a research on the determinants of dividend payout of Nifty-100 index firms help to generalize the determinants of dividend payout in the Indian market. Thus, it will be an additional input to the theory of dividend policies. In present study, it is found that, lagged dividend and growth opportunities significantly influence dividend payout of Nifty 100 index firms.
\end{abstract}

KEYWORDS: Dividend policy, value of the firm, market capitalization, corporate tax

\section{INTRODUCTION}

Dividend decision in one of the most significant decision a firm's management has to take. It deals with the retention or distribution of net earnings of a firm. A firm's management has to ensure that, such dividend decision shall be able to satisfy the needs of various categories of shareholders. Thus, such decision resulted in higher firm value.

There are two different theoretical strands address the dividend and value of the firm. The first groups of theory are dividend irrelevance theories those argue the value of the firm is independent of its dividend decision. The second, group of theories are dividend relevance theories, which argue that; dividend payout influences on the value of the firm. There are large numbers of the researches which have been arguing that, the dividend payout influences on the value of the firm(Cristea and Cristea, 2017; Echchabi and Azouzi, 2016; Herawati and Fauzia, 2018). The main question of studies on dividend is - 'what are the determinants of dividend payout?'(Cristea and Cristea,
2017; Echchabi and Azouzi, 2016; Gowri and Saravanan, 2016).

In the studies on dividend determinants it can be find that, the determinants of the dividend payout vary from one study to another. But, there are some determinants which are common in many studies. Though there are many studies have been conducted on the determinants of dividend payout. But, a study on NIFTY-100 index that covers more than 70 free float market capitalization of firms which are trading in the NSE. Hence, a study on such sample can be generalized to entire economy. Thus, it would be an addition to existing theoretical knowledge on the dividend payout.

The present study is organized as follows: section one deals with the introduction, section two focused on the review of literature, section three states research question and objective of the study, section four is research methodology, section five throws light on results and discussion, section six deals with the conclusion. 


\section{REVIEW OF LITERATURE}

In this section the brief review of past researches on the dividend policies have been carried out.

Linter's (1956) study is the mile stone on the determinants of dividend payout. After the interview of various experts in different industries he found that, 'current year's earnings and lagged dividend' are the two important factors those influence on the dividend payout. Thus, this model is called as the two factors model.

Darling (1957) is of the view that 'previous year profit better explains the current year's dividend than the previous year dividend' and thus substitutes previous year profits in place of previous year dividend in Lintner's model. This model uses current year's PAT, lagged PAT, depreciation and amortization expenses and change in sales over two previous two years as independent variables

Britain (1966) studied the major industries over a period of 1919-1960. Results indicated that, 'Current year's cash profits and previous year's dividends influence on the dividend policy of a firm'. Later Brittain's explicit depreciation Model has been developed, this model uses current year's PAT and depreciation and amortization expenses as separate variables and previous year's dividends as independent variables.

Karampal and Puja Goyal (2009) in their study found that 'lagged dividend, Profit after tax, depreciation and sales' significantly influence on the dividend payout of the sample firms.

Gupta A and C Banga (2010) examined the various factors that have a bearing on the dividend decision of a firm by using a two-step multivariate procedure. Results of factor analysis indicated that 'leverage, liquidity, profitability, growth and ownership structure' were the major factors those influence on the dividend payout of the sample firms.

Marfo-Yiadom and Agyei (2011) in their paper attempted to analyze determinants of dividend policy of banks in Ghana. The results showed that- 'profitability, debt, changes in dividend and collateral capacity' are the statistically significant factors which positively influence dividend policy.

Rizvi and Khare (2011) analyzed the determinants of dividend payout ratio for BSE BANKEX listed companies in India. In the study it is found that- ' EBIT, Beta, PBIT/ Total assets' had been found to be significant determinants.

Echchabi and Azouzi, (2016) have conducted their study on determinants of dividend payout in Tunusia firms, it is found that, "net cash flow and market to book value' have significant impact on the dividend payout of the sample firms.

Gowri and Saravanan, (2016) in their study on the determinants of the dividend payout, they have considered 'Earnings per share, lagged Dividend per share, Age of the firm, Size of the firm, Growth of the firm, Tangibility of the firm, Debt equity ratio, Operating profit ratio, Net profit ratio, Net profit to Net worth ratio, and Operating cost ratio' and it is found that all these variables significantly influence on the dividend payout of the firms in the Indian cement industry.

Cristea and Cristea, (2017) in their study on the Determinants of corporate dividend policy: evidence from Romanian listed companies; it is found that, 'dividend policy is positively related to corporate profitability and liquidity and negatively associated with leverage, size, growth, and the state of the economy'.

Herawati and Fauzia, (2018) in their study made an attempt to examine the effect of Current Ratio, Debt to Equity Ratio and Return on Asset on Dividend Payout Ratio in Sub-sector automotive and Component Listed in Indonesia Stock. It is found that 'debt equity ratio and return on assets' are the two factors significantly influence on the dividend payout.

The findings of the various researches on the determinants of dividend payout reveal that, large number of financial variables influence on the dividend payout. The review of the above researches provides a strong basis for the selection of the different factors those influence on the dividend payout of the sample firms.

Based on the above empirical researches the following determinants of dividend payout are considered for the empirical examination of the present study, they are- Current year's Profitability(CPR), Free Cash flows (FCF), Capital Expenditure(CAPEX), Corporate Tax Rate(CTAX), Change in Total sales(CSALES), Size of the firm (SIZE), Leverage(LEV), Age(AGE), Cash Profit (CPROF), Liquidity, Lagged Dividend (dLDPR).

\section{RESEARCH QUESTION AND OBJECTIVE OF THE STUDY}

There are large number of studies have been conducted to examine the determinants of dividend payout across different countries and in different industrial sectors(Cristea and Cristea, 2017; Echchabi and Azouzi, 2016). In Indian context also there are number of studies have been conducted to examine the determinants of dividend payout across different industrial sectors(Gowri and Saravanan, 2016; Gupta and Banga, 2010). As the firms in the NIFTY-100 index represent large number of diversified sectors in India, the study on the dividend determinants of these firms can be generalized. The research question of the study is- "what are the determinants of the dividend payout of the NIFTY-100 firms?' Specifically the 
present study deals with the following objective: To empirically examine the determinants of the dividend payout of the NIFTY-100 index firms.

\section{Hypotheses}

H0: Select determinants do not significantly influence on the dividend payout of NSE-100 firms

H1: Select determinants significantly influence on the dividend payout of NSE-100 firms

\subsection{RESEARCH METHODOLOGY \\ 4.1 Data and source}

The present study is based on the secondary data. The data for the study has been collected from the Capitalize data base, NSE and other published sources. The validity of the data has been cross checked with the randomly selected firms' annual reports and it is found no differences in the data.

\subsection{Sample and sample size}

As the study is based on the NIFTY-100 index, for the present study all the non-financial firms which being consistently part of NIFTY-100 index from 2010 to 2019 are select for the study. After, screening by the above condition, the final sample reached 39 nonfinancial firms. The index NIFTY 100 is represented by top 100 diversified stocks based on their market capitalization. The NIFTY 100 Index represents about $76.8 \%$ of the free float market capitalization of the stocks listed on NSE as on March 29, 2019(NSE indices.com).

\subsection{Tools and Techniques for the data analyses}

For the data analyses, it is used MS excel and Stata-13 version. The ratios and percentages of different variables have been collected. To examine the fundamental characteristics of the data, descriptive statistics have been employed. Further, it is ensured that, the data has to be satisfied with the basic assumptions of models.

\subsection{Normality Tests}

The Normality tests are conducted to examine whether the data is properly modelled by a normal distribution or not. In the study Jarque-Bera test has been conducted. This test measures the difference of the skewness and kurtosis of the series with those from the normal distribution.
The statistic is computed as:

$$
\text { Jarque-Bera }=\frac{N}{6}\left(S^{2}+\frac{(K-3)^{2}}{4}\right)
$$

Kurtosis.

Where S means Skewness, and K- mean

\subsection{Panel data analysis}

In the study there are 39 firms whose data has been obtained from March 2010 to march 2019. Hence, the data has both cross section and time series components. Thus, it is appropriate to use panel data analysis that considers cross-section and time effects.

\subsection{Fixed effect model vs Random effect} model

The applicability of the models depend on whether the cross section error components are correlated with the independent variables(Haldar et al., 2010). If they are correlated with the independent variables the Random effect model will be in appropriate to use. To test whether cross section error components are correlated with the explanatory variables we conducted Hausman test of cross-section random effects. If they are correlated, we use the fixed effect model.

The transformed data panel unit root, the random effect and fixed effect models (within) have been conducted, then Hausman Test is conducted, to decide which model is more appropriate. which shows the significant correlation of cross section error components with the explanatory variables.

Thus, to conduct fixed effect model. Finally, we have conducted two -way fixed effect model.

Our model is as follows:

$$
y i t=\alpha_{\mathrm{i}}+\lambda_{\mathrm{t}}+\beta_{1} \mathrm{x}_{1 \mathrm{it}}+\ldots \ldots . .+\beta \mathrm{kx}_{\mathrm{kit}}+\text { uit, }
$$

where:

$>a_{i-t}$ he individual specific intercept

$>\lambda_{\mathrm{t}}$-the time specific intercept

$>$ uit- $\mathrm{N}\left(0, \sigma^{2} \mathrm{u}\right)$

To test the fixed effect model, random effect model and Hausman Test we used STAT-13. 


\section{8: Variables}

Table-1: The variables and their measurement

\begin{tabular}{|c|c|c|c|}
\hline $\begin{array}{c}\text { Sl } \\
\text { No }\end{array}$ & Variable & Measurement & $\begin{array}{c}\text { Theoretic } \\
\text { al } \\
\text { predicted } \\
\text { relation }\end{array}$ \\
\hline 1 & Dividend payout & Total Cash Dividends Paid/ Total paid up share capital. & - \\
\hline 2 & $\begin{array}{c}\text { Current year's } \\
\text { Profitability(CPR) }\end{array}$ & Net Profit/Net worth & Positive \\
\hline 3 & Free Cashflows(FCF) & $\begin{array}{l}\text { (Profit after tax }+ \text { Depreciation and amortization }+ \\
\text { interest)-capital expenditure/total assets }\end{array}$ & Positive \\
\hline 4 & $\begin{array}{c}\text { Capital } \\
\text { Expenditure(CAPEX) }\end{array}$ & Change in the gross fixed assets/ Total assets $\mathrm{s}_{\mathrm{t}-1}$ & Negative \\
\hline 5 & Corporate Tax Rate(CTAX) & Corporate tax paid $/ \mathrm{EBT}_{\mathrm{t}}$ & Negative \\
\hline 6 & $\begin{array}{l}\text { Change in Total } \\
\text { sales(CSALES) }\end{array}$ & The current period sales - previous two year's sales & Negative \\
\hline 7 & Size of the firm (SIZE) & Natural log of total assets & Positive \\
\hline 8 & Leverage(LEV) & (Long-term debt/Total assets $t_{t}$ & Negative \\
\hline 9 & $\begin{array}{c}\text { Growth } \\
\text { opportunities(GWOP) }\end{array}$ & Market value of equity/ book value of equity & Negative \\
\hline 10 & Cash Profit (CPROF) & Net Profit+ Depreciation and Amortization & Positive \\
\hline 11 & Age(AGE) & $\begin{array}{l}\text { Natural logarithm of number of years from its } \\
\text { incorporation }\end{array}$ & $\begin{array}{l}\text { Positive/ } \\
\text { Negative }\end{array}$ \\
\hline 112 & Lagged Dividend (dLDPR) & $\begin{array}{c}\text { Total Cash Dividends Paid }{ }_{\mathrm{t}-1} / \text { Total paid up share } \\
\text { capital }_{\mathrm{t}-1}\end{array}$ & Positive \\
\hline
\end{tabular}

\section{RESULTS AND DISCUSSION \\ 5.1 Descriptive statistics}

Table-2: Descriptive Statistics

\begin{tabular}{|c|c|c|c|c|c|c|c|}
\hline Variable & Obs & Mean & Std.Dev. & Min & Max & Skewness & Kurtosis \\
\hline DPR & 390 & 4.265 & 10.613 & 0 & 132.944 & 6.649 & 66.147 \\
\hline CPR & 390 & 6211.699 & 7931.64 & -5017.32 & 45721 & 2.437 & 9.498 \\
\hline FCF & 351 & 0.129 & 0.493 & -4.364 & 3.918 & -2.779 & 51.261 \\
\hline CAPEX & 351 & 0.216 & 1.173 & -0.607 & 16.266 & 10.021 & 119.258 \\
\hline CTAX & 390 & 0.186 & 0.235 & -0.311 & 3.391 & 10.761 & 140.362 \\
\hline CSALES & 351 & 4030.584 & 13013.07 & -95918 & 81734 & .4967 & 24.518 \\
\hline SIZE & 390 & 9.874 & 1.297 & 5.801 & 13.253 & -.0938 & 2.951 \\
\hline LEV & 390 & 0.168 & 0.201 & 0 & 0.722 & 1.033 & 2.908 \\
\hline GWOP & 390 & 5.67 & 7.22 & 0.238 & 50.758 & 3.217 & 15.329 \\
\hline CPROF & 390 & 0.202 & 0.224 & -1.338 & 1.42 & .6858 & 16.667 \\
\hline AGE & 390 & 45.423 & 25.756 & 3 & 112 & .6563 & 2.471 \\
\hline dDPR & 351 & 4.536 & 10.975 & 0 & 132.944 & 6.565 & 63.558 \\
\hline
\end{tabular}

In the above table- 2 the results of descriptive statistics has been presented. The mean dividend payout ratio is 4.26 which indicate higher dividend payout by the NIFTY-100 indexed firms. The current year's mean profit is Rs. 6211.70 crores that vary from negative profit of Rs. -5017.32 to maximum of Rs. 45721 crores. The mean free cash flows are 0.129 times of total an asset, which indicates less amount of free cash flows are compared to their total assets. The mean capital expenditure ratio is 0.216 which indicates the 
firms in the sample spend lesser amount as their capital expenditure. The mean tax ratio is 0.186 . The mean change in the sales is Rs. 4030.58 crores which reveals there is higher volatility in the sales of the firm. The mean size of the sample firms is 9.874 , that indicates the firms in the sample are larger in size and that may positively influence on the dividend payout of the sample firms. Further the above table- 2 also depicts that, the mean leverage is 0.168 which vary from 0 to 0.722 times indicating on the average the firms in the sample have moderate amount of leverage. Whereas the firms in the sample exhibit a mean growth opportunity of 5.67. The mean cash profit of the firms in the sample is 0.202 times of profit after tax, which indicates the firms in the sample have lesser amount of cash profits. The mean age of the firms in the sample is 45.42 which indicate the firms in the sample have been persisting in the market over the longer period of time.

\subsection{Summary of Results of Fixed-effects (within) regression \\ Table-3 Fixed-effects (within) regression}

\begin{tabular}{|ccc|}
\hline Variable & Coef. & P-value \\
\hline CPR & 0.0000262 & $(0.911)$ \\
\hline FCF & -1.023 & $(0.462)$ \\
\hline CAPEX & -0.366 & $(0.666)$ \\
\hline CTAX & 0.00605 & $(0.998)$ \\
\hline CSALES & -0.00000766 & $(0.840)$ \\
\hline SIZE & -3.149 & $(0.191)$ \\
\hline LEV & -0.441 & $(0.958)$ \\
\hline GWOP & $0.428^{*}$ & $(0.030)$ \\
\hline CPROF & 6.977 & $(0.100)$ \\
\hline AGE & 0.0660 & $(0.833)$ \\
\hline dDPR & $0.175^{* *}$ & $(0.002)$ \\
\hline Cons & 28.09 & $(0.103)$ \\
\hline \multirow{3}{*}{351} \\
\hline N
\end{tabular}

The summary of results of the fixed effect model has been presented in the above table- $3 *$. As the F-value is 3.14 and the p-value is 0.00 the null hypothesis is rejected. This indicates the select determinants significantly influence on the dividend payout of the NSE-100 firms. Further, it is also found that, of the all independent variables, growth opportunities and lagged divided significantly influence on the dividend payout at 5 percent and 1 percent level of significance. The positive and significant value of lagged dividend indicates the firms wish to maintain constant dividend payout policy. Hence, the lagged dividend payout positively influenced on the dividend payout.

- Initially both fixed effect and random effect models were conducted, to decide which one of the fixed effect and random effect models is appropriate.. Based on the Hausman Test Fixed effect model is appropriate, hence finally the fixed effect model has been conducted.

The positive and significant value of growth opportunities indicate the firms those have high growth opportunities pay higher dividend. These results are in opposite to theoretically the expected sign. 
Theoretically it is expected that, the firms those have high growth opportunities retain the funds for their further growth and expansion, hence it is expected that a firm's growth opportunities negatively influence on the dividend payout.

Whereas, the results show, positive relationship between the dividend payout and growth opportunities. The probable reason for such result is- as the firms in the Nifty 100 index are highly reputed and they have mean age of 45.42 years, which indicates the firms have been persisting over the longer period of time in the market and they have higher reputation. Therefore, they can be easily raise required funds from the market even if they won't retain their earnings. Hence, they have paid higher dividend when they have higher growth opportunities to attract more investors.

\section{CONCLUSION}

Dividend decision is one of the important decisions a firm's management has to take. Though there are large number of studies have been conducted on the dividend policies. Still it is unsettled puzzle in the area of corporate finance. The present study has been conducted to examine the determinants of dividend payout of NIFTY-100 index firms. The National stock exchange's Nifty 100 index covers the top 100 firms which represents large number of diversified sectors of the Indian economy. The firms in the Nifty 100 index represents $76.8 \%$ of the free float market capitalization of the stocks listed on NSE as on March 29, 2019(NSE indices.com). This shows the significant coverage of the index. Hence, a research on such firms can be generalized.

Based on the past researches there are eleven independent variables those influence on the dividend policy has been identified. Of these only lagged dividend and growth opportunities are positively and significantly influence the dividend payout of the sample firms at 5 percent and 1 percent level of significant; remaining all other independent variables do not have significant influence on the dividend payout of the sample firms. Thus, based on the result of the study it can be concluded that lagged dividend and growth opportunities significantly influence on the dividend payout of the Nifty 100 index firms.

\section{REFERENCES}

1. Amitabh Gupta and Charu Banga (2010), "The Determinats of Corporate Dividend Policy", Decision, Vol.37, No.2, pp. 63-76.

2. Cristea, C., Cristea, M., 2017. Determinants of corporate dividend policy: evidence from romanian listed companies. MATEC Web Conf. 126, 04009. https://doi.org/10.1051/matecconf/201712604009

3. Brittain, John A (1964), "The Tax Structure and Corporate Dividend Policy", The American
Economic Review, Vol. 54, No. 3, (May), Papers and Proceedings of the Seventy -sixth Annual Meeting of the American Economic Association, pp. 272-287.

4. Brittain, John. A. (1966), "Corporate Dividend Policy”, The Brooking Institution, Washington D.C.

5. Echchabi, A., Azouzi, D., 2016. Determinants of Dividend Payout Ratios In Tunusia: Insights In Light of The Jasmine Revolution 13.

6. Gowri, D.K., Saravanan, D.R., 2016. Determinants Of Dividend Policy Of Select Companies In Indian Cement Industry - A Structural Equation Modeling 5,13 .

7. Gupta, A., Banga, C., 2010. The Determinants of Corporate Dividend Policy. Decis. 0304-0941 37.

8. Haldar, A., Rao, S.N., Tayde, M., 2010. Ownership structure and firm performance: Evidence from India. Huntsville Tex. USA 96.

9. Herawati, A., Fauzia, F.I., 2018. The Effect of Current Ratio, Debt to Equity Ratio and Return on Asset on Dividend Payout Ratio in Sub-sector Automotive and Component Listed in Indonesia Stock Exchange in Period 2012-2016. KnE Soc. Sci.

10. Karampal and Puja Goyal (2009), "Corporate Dividend Policy in Indian IT Industy”, Finance India, VolXXIII, No.4, 2009,pp 1295-1316.

11. Lintner, John (1956), “Distribution of Incomes of Corporations Among Dividens, Retained Earnings, and Taxes", The American Economic Review, Vol. 46, No. 2, Papers and Proceedings of the Sixtyeighth Annual Meeting of the American Economic Association (May), pp. 97-113.

12. Rizvi and Khare (2011), "Determinants of Dividend Payout ratios-A study of the Indian Banking Sector", Indian Journal of Finance, Feb 2010, pp.24-31. 